\title{
IMPLEMENTASI DIVERSI GUNA MEWUJUDKAN RESTORATIVE JUSTICE DALAM SISTEM PERADILAN PIDANA ANAK.
}

\author{
Aryani Witasari \\ Fakutal Hukum Unissula \\ aryani@unissula.ac.id \\ Muhammad Sholikul Arif \\ Fakultas Hukum Unissula \\ Msarief3234@gmail.com
}

\begin{abstract}
The research objective is to identify and analyze the implementation of Diversion in order to realize Restorative Justice in the Juvenile Criminal Justice System in an effort to provide legal protection for child criminal offenders. The approach method used in this research is normative juridical or library law research or doctrinal law research, namely legal research by examining library materials and secondary materials, the results of the study found that the obligation to seek diversion with the Restorative Justice approach at every stage in the criminal justice process Children must be carried out in the Criminal Justice System, Diversion as a step towards transferring the settlement of children's cases from the criminal justice process to non-criminal justice processes by prioritizing the Restorative Justice approach which can be carried out by way of deliberation or mediation which emphasizes efforts to restore back to its original state in a friendly manner.
\end{abstract}

Keyword: Child justice system, Diversion, Restorative Justice;

\section{A. Pendahuluan}

Perlindungan anak merupakan upaya-upaya yang mendukung terlaksananya hak-hak dan kewajiban. Seorang anak yang memperoleh dan mempertahankan hak untuk tumbuh dan berkembang dalam hidup secara berimbang dan positif, berarti mendapat perlakuan secara adil dan terhindar dari ancaman yang merugikan. Usaha-usaha perlindungan anak dapat merupakan suatu tindakan hukum yang mempunyai akibat hukum, sehingga 
menghindarkan anak dari tindakan orang tua yang sewenangwenang. ${ }^{1}$

Di Indonesia telah dibuat peraturan-peraturan yang pada dasarnya sangat menjunjung tinggi dan memperhatikan hak-hak dari anak, yaitu diratifikasinya Konvensi Hak Anak (KHA) dengan keputusan Presiden Nomor 36 Tanggal 25 Agustus Tahun 1990. Peraturan perundangan lain yang telah dibuat oleh pemerintah Indonesia antara lain Undang-Undang Nomor 4 Tahun 1979 tentang Kesejahteraan Anak, Undang-Undang Nomor 39 Tahun 1999 tentang Hak Asasi Manusia, Undang-Undang Nomor 23 Tahun 2002 tentang Perlindungan Anak, Undang-Undang Nomor 3 tahun 1997 tentang Pengadilan Anak yang kemudian diganti dengan Undang-Undang Nomor 11 Tahun 2012 tentang Sistem Peradilan Pidana Anak, dimana secara substansinya undang-undang tersebut mengatur hak-hak anak yang berupa, hak hidup, hak atas nama, hak pendidikan, hak kesehatan dasar, hak untuk beribadah menurut agamanya, hak berekspresi, berpikir, bermain, berkreasi, beristirahat, bergaul dan hak jaminan sosial.

Dengan diundangkannya Undang-Undang Republik Indonesia Nomor 11 Tahun 2012 tentang Sistem Peradilan Pidana Anak merupakan pergantian terhadap Undang-Undang Nomor 3 Tahun 1997 tentang Pengadilan Anak, yang dilakukan dengan tujuan agar dapat terwujud peradilan yang benar-benar menjamin kepentingan terbaik terhadap anak yang berhadapan dengan hukum sebagai penerus bangsa.

Oleh karena itu sudah seharusnya sistem pemidanaan terhadap anak yang berhadapan dengan hukum harus memperhatikan kepentingan anak dan sesuai dengan standar nilai dan perlakuan sejumlah instrumen nasional maupun internasional yang berlaku untuk

${ }^{1}$ Moch. Faisal Salam, 2005, Hukum Acara Peradilan Anak di Indonesia, Cetakan I, Mandar Maju, Bandung, hlm.1 
anak. Semua instrumen hukum internasional dan istrumen hukum nasional ini dimaksudkan untuk memberikan jaminan perlindungan hak-hak anak.

Lahirnya Undang-Undang Nomor 11 Tahun 2012 tentang Sistem Peradilan Pidana Anak pada tanggal 3 Juli 2012, patut kita apresiasi bersama sebagai salah satu pembaharuan hukum di masa mendatang. Lahirnya undang-undang itu meski baru berlaku 2 (dua) tahun sejak diundangkan yakni tahun 2014, setidaknya memberi "Nafas" baru bagi anak, dimana kepentingannya perlu mendapatkan perlakuan hukum "Istimewa", terutama ketika sang anak tersebut melakukan tindak pidana.

Undang-Undang Nomor 11 Tahun 2012 telah memberikan pembedaan perlakuan dan perlindungan terhadap pelaksanaan hak-hak dan kewajiban anak, khususnya anak sebagai tersangka dalam proses peradilan pidana, yaitu meliputi seluruh prosedur acara pidana, mulai dari penyelidikan, penyidikan dan berakhir pada pelaksanaan pidana.

Dalam penerapan sanksi pidana terhadap anak yang melakukan tindak pidana berbeda perlakuannya dengan orang dewasa yang melakukan tindak pidana. Semuanya jelas dilandaskan pada asas kepentingan terbaik bagi anak, sebagaimana yang diamanatkan dalam konvensi internasional tentang hak-hak anak.

Melihat prinsip tentang perlindungan anak terutama mengenai prinsip non diskriminasi yang mengutamakan kepentingan terbaik bagi anak dan hak untuk hidup, kelangsungan hidup, dan tumbuh kembang anak sehingga diperlukan penghargaan terhadap anak, termasuk terhadap anak yang melakukan tindak pidanan. Oleh karena itu maka diperlukan suatu sistem peradilan pidana anak yang di dalamnya terdapat proses penyelesaian perkara anak di luar mekanisme pidana konvensional. 
Muncul suatu pemikiran atau gagasan untuk hal tersebut dengan cara pengalihan atau biasa disebut ide Diversi, karena lembaga pemasyarakatan bukanlah jalan untuk menyelesaikan permasalahan anak dan justru dalam Lembaga Pemasyarakatan rawan terjadi pelanggaran-pelanggaran terhadap hak anak. Hal inilah yang mendorong ide Diversi khususnya melalui konsep Restorative Justice menjadi suatu pertimbangan yang sangat penting dalam menyelesaikan perkara pidana yang dilakukan oleh anak, konsep ini telah diatur di dalam Undang-Undang Nomor 11 Tahun 2012 tentang Sistem Peradilan Pidana Anak.

Seorang anak yang melakukan tindak pidana wajib disidangkan di pengadilan khusus anak yang berada di lingkungan peradilan umum, dengan proses khusus serta pejabat khusus yang memahami masalah anak, mulai dari penangkapan, penahanan, proses mengadili dan pembinaan. Sementara itu dari perspektif ilmu pemidanaan, meyakini bahwa penjatuhan pidana terhadap anak nakal cenderung merugikan perkembangan jiwa anak di masa mendatang, Kecenderungan merugikan ini akibat dari efek penjatuhan pidana terutama pidana penjara, yang berupa stigma (cap jahat) terhadap anak pelaku tindak pidana.

Hubungan dengan penegakan hukum pidana, maka Restorative Justice merupakan suatu pendekatan dalam memecahkan masalah pidana yang melibatkan korban, pelaku, serta elemen-elemen masyarakat demi terciptanya suatu keadilan.

Terhadap kasus tindak pidana yang dilakukan oleh anak, maka Restorative justice setidak-tidaknya bertujuan untuk memperbaiki atau memulihkan perbuatan kriminal yang dilakukan anak dengan tindakan yang bermanfaat bagi anak, korban dan lingkungannya yang melibatkan mereka secara langsung dalam penyelesaian masalah, dan 
berbeda dengan cara penanganan orang dewasa.

Dalam Pasal 1 butir (6) Undang-Undang Nomor 11 Tahun 2012 tentang Sistem Peradilan Pidana Anak menyatakan, Keadilan Restoratif adalah penyelesaian perkara tindak pidana dengan melibatkan pelaku, korban, keluarga pelaku/korban, dan pihak lain yang terkait untuk bersama-sama mencari penyelesaian yang adil dengan menekankan pemulihan kembali pada keadaan semula, dan bukan pembalasan.

Pasal 5 Undang-Undang Sistem Peradilan Pidana Anak wajib mengutamakan pendekatan Keadilan Restoratif, yang meliputi:

a. penyidikan dan penuntutan pidana Anak yang dilaksanakan sesuai dengan ketentuan peraturan perundang-undangan, kecuali ditentukan lain dalam undang-undang ini;

b. persidangan Anak yang dilakukan oleh pengadilan di lingkungan peradilan umum; dan

c. pembinaan, pembimbingan, pengawasan, dan/atau pendampingan selama proses pelaksanaan pidana atau tindakan dan setelah menjalani pidana atau tindakan.

Dalam Undang-Undang Sistem Peradilan Pidana Anak sebagaimana dimaksud pada Pasal 1 butir (7) wajib diupayakan Diversi. Diversi adalah pengalihan penyelesaian perkara Anak dari proses peradilan pidana ke proses di luar peradilan pidana.

Secara prinsipiil melalui Undang-Undang Nomor 11 Tahun 2012 telah mengedepankan pendekatan Restorative Justice dan proses Diversi sebagai upaya penyelesaian tindak pidana yang dilakukan oleh anak, sehingga penerapan Restorative Justice akan menawarkan jawaban atas isu-isu penting dalam penyelesaian perkara pidana, yaitu: pertama, kritik terhadap sistem peradilan pidana yang tidak memberikan kesempatan khususnya bagi korban; kedua, menghilangkan konflik khususnya antara pelaku dengan korban dan 
masyarakat; ketiga, fakta bahwa perasaan ketidakberdayaan yang dialami sebagai akibat dari tindak pidana harus diatasi untuk mencapai perbaikan.

Penerapan prinsip Restorative Justice dan proses Diversi sebagai upaya penyelesaian tindak pidana yang dilakukan oleh anak walaupun secara yuridis formil telah diatur secara jelas dan tegas di dalam Undang-Undang Nomor 11 Tahun 2012, namun secara formil pula muncul permasalahan terkait dengan waktu berlakunya undangundang tersebut yang pada Pasal 108 disebutkan: undang-undang ini mulai berlaku setelah 2 (dua) tahun terhitung sejak tanggal diundangkan" yang berarti undang-undang tersebut baru berlaku pada bulan Juli Tahun 2014, hal ini tentu akan memunculkan permasalahan bagi penyelesaian tindak pidana yang melibatkan anak, disamping itu kesiapan bagi seluruh aparatur penegak hukum, pemahaman masyarakat, dan sarana serta pra-sarana menjadi faktor pendukung yang tidak dapat dikesampingkan dalam menunjang berlakunya undang-undang tersebut. Ketika faktor pendukung tersebut tidak memadai maka akan menimbulkan permasalahan kembali dan tentunya akan berimbas bagi anak baik langsung maupun tidak langsung.

\section{B. METODE PENELITIAN}

Metode pendekatan yang digunakan dalam penelitian ini adalah Yuridis normatif atau penelitian hukum kepustakaan atau penelitian hukum doktrinal, yaitu penelitian hukum dengan cara meneliti bahan pustaka dan bahan sekunder, yang dalam hal ini berkaitan dengan Diversi melalui keadilan Restorative Justic dalam upaya memberikan perlindungan hukum terhadap pelaku tindak pidana anak 


\section{HASIl PENELITIAN DAN PEMBAHASAN}

\section{Implementasi Diversi guna mewujudkan Restorative}

\section{Justice dalam Sistem Peradilan Pidana Anak.}

Untuk melakukan perlindungan kepada anak dari pengaruh proses formal sistem peradilan pidana, maka timbul pemikiran manusia atau para ahli hukum untuk membuat aturan formal tindakan mengeluarkan seorang anak yang melakukan pelanggaran hukum atau melakukan tindak pidana dari proses peradilan pidana dengan memberikan alternatif lain yang dianggap lebih baik untuk anak. Berdasaran pikiran tersebut, maka lahirlah konsep Diversion yang dalam istilah Bahasa Indonesia disebut Diversi atau pengalihan di dalam proses Peradilan anak.

Pelaksanaan Diversi dilatarbelakangi keinginan menghindari efek negatif terhadap jiwa dan perkembangan anak oleh keterlibatannya dengan sistem peradilan pidana yang mengutamakan penyelesaian secara kekeluargaan dengan upaya pendekatan Restorative justice.

Dengan adanya Diversi yang telah diatur dalam UndangUndang Nomor 11 Tahun 2012 tentang Sistem Perdilan Pidana Anak diharapkan dapat mempermudah pengalihan proses pidana di luar pemidanaan dengan mengunakan pendekatan Restorativ Justice yang dapat menyelamatkan anak untuk masa depan.

Restorative Justice merupakan proses penyelesaian yang dilakukan di luar sistem peradilan pidana dengan melibatkan korban, pelaku, keluarga korban dan pelaku, masyarakat serta pihak-pihak yang berkepentingan dengan suatu tindak pidana yang terjadi untuk mencapai kesepakatan dan penyelesaian. Restorative justice dianggap cara berfikir/paradigma baru dalam memandang sebuah tindak kejahatan yang dilakukan oleh seorang Anak yang melakukan 
pelanggaran hukum atau melakukan tindakan criminal, tentunya dalam tindakannya sangat dipengaruhi beberapa faktor lain di luar diri anak.

Pelaksanaan sistem peradilan pidana anak di Indonesia secara bertahap dilakukan dengan proses penyelidikan, penyidikan, proses penuntutan, proses pemeriksaan dipengadilan dan proses pelaksanaan putusan hakim. Adapun lembaga-lembaga yang terkait dengan proses pemeriksaan pengadilan anak yaitu : Kepolisian, Balai Pemasyarakatan (Bapas), Kejaksaan, Pengadilan, Penasehat Hukum dan Lembaga Pemasyarakatan Anak. Sehubungan dengan tahapan dari lembaga yang Terkait dengan proses peradilan pidana anak ini, maka uraian dalam sub bab ini tentang implementasi Diversi guna mewujudkan Restorative Justice dalam Undang-Undang Nomor 11 tahun 2012 tentang Sistem Peradilan Pidana Anak yang mengutamakan Penyelesaian Secara Kekeluargaan.

Dalam menyelesaikan perkara anak, anak harus diberi perlindungan dan diberlakukan secara khusus. Seperti dalam Pasal 17 ayat (1) Undang-Undang Nomor 11 Tahun 2012 tentang Sistem Peradilan Pidana Anak. "Penyidik, Penuntut Umum, dan Hakim wajib memberikan perlindungan khusus bagi Anak yang diperiksa karena tindak pidana yang dilakukannya dalam situasi darurat". Hal ini mengingat sifat dan psikis anak dalam beberapa hal tertentu memerlukan perlakuan khusus, serta perlindungan yang khusus pula, terutama pada tindakan-tindakan yang dapat merugikan perkembangan mental maupun jasmani anak.

Mekanisme pelaksanaan Diversi dalam tahap penyidikan terhadap tindak pidana anak dengan mengunakan pendekatan Restorative Justice dapat dilakukan melalui cara musyawarah atau mediasi dengan menekankan pemulihan kembali pada keadaan 
semula dalam menyelesaikan konflik anak. Penyelesaian secara musyawarah ini tidak akan terealisasikan apabila tidak ada kerjasama antara korban, pelaku tindak pidana, masyarakat dan penyidik. Penyidik atau pihak kepolisian sebagai pintu gerbang dari Sistem Peradilan Pidana Anak dan pihak yang berwenang pertama kali menentukan posisi seorang anak yang berhadapan dengan hukum, Pihak kepolisian harus menggunakan kewenangan Diskresi yang merupakan bagian dari proses pengalihan hukum.

Diskresi diberikan kepada penyidik untuk mengupayakan Diversi dengan menggunakan pendekatan Restorative Justice. penerapan Diskresi dalam Sistem Peradilan Pidana Anak adalah kebijakan penyidik anak dalam menetapkan suatu perkara anak nakal, tidak dilanjutkan pemeriksaanya dengan pertimbangan hukum yang sesuai dengan perundang-undangan demi kepentingan terbaik bagi anak.

Diskresi yang diberikan negara terhadap salah satu sub sistem peradilan ini dalam mengemban tugas menjaga dan melindungi ketertiban dan keamanan dalam masyarakat serta menanggulangi kejahatan, spesifikasinya terhadap pelaku tindak pidana anak di bawah umur maka tindak pidana ini dialihkan dari proses formal ke proses informal (Diversi), yaitu dengan menggunakan pendekatan Restorative justice, di mana titik berat penyelesaian konflik atau persengketaan dengan mendudukan korban, pelaku dan masyarakat di sekitar tempat terjadinya tindak pidana anak di bawah umur dan difasiltasi oleh seorang mediator. Yang dapat menjadi mediator bisa saja Hakim, Polisi, Jaksa karena proses mediasi bisa disemua tahap (dapat dikaitkan pada Pasal 7 ayat (1) Undang-Undang Sistem Peradilan Pidana Anak). Tujuan dari perdamaian ini agar perselisihan ini bisa saling memaafkan dan tidak 
perlu dibawa ke pengadilan karena dari kedua belah pihak telah merasa puas dengan mediasi yang telah dilakukan.

Adapun cara mediasi yang dapat dilakukan dalam penerapan Restorative Justice adalah :

a. Victim offender mediatian (VOM) adalah Forum Mediasi antara pelaku dan korban yaitu suatu forum yang mendorong adanya pertemuan antara pelaku dan korban yang dibantu oleh mediator sebagai koordinator dan fasilitator dalam pertemuan tersebut ${ }^{2}$

b. Family group conferencing (FGC) yaitu suatu forum yang sama dengan VOM, namun dalam bentuk ini terdapat perbedaan yaitu pelibatan penyelesaian bukan hanya melibatkan pelaku dan korban langsung, tetapi juga korban tidak langsung, seperti keluarga atau kawan dekat korban serta keluarga dan kawan dekat pelaku. Adapun alasan pelibatan para pihak tersebut adalah karena mereka mungkin terkena dampak baik langsung ataupun tidak langsung atas tindak pidana yang terjadi atau mereka memiliki keperdulian yang tinggi dan kepentingan akan hasil dari musyawarah serta mereka juga dapat berpartisipasi dalam mengupayakan keberhasilan proses dan tujuan akhirnya. ${ }^{3}$

c. Circles yaitu proses mediasi yang pelibatannya lebih luas dibandingkan dengan dua bentuk sebelumnya, yaitu forum yang bukan hanya korban, pelaku, keluarga atau mediator saja tapi juga anggota masyarakat yang merasa berkepentingan dengan perkara tersebut. ${ }^{4}$

${ }^{2}$ Marlina, 2009, Peradilan Pidana Anak Di Indonesia. "Pengembangan Konsep Diversi dan Restorative Justice", PT. Refika Aditama, Bandung, hlm. 181

${ }^{3}$ Ibid. Hlm. 188

${ }^{4}$ Ibid. Hlm. 192 
d. Reparative Board/Youth Panel yaitu Proses mediasi yang pelibatanya paling luas dibandingkan dengan ketiga bentuk mediasi sebelumnya dengan melibatkan pelaku, korban, masyarakat, mediator dan juga hakim, jaksa dan pembela secara bersama merumuskan bentuk sangsi yang tepat bagi pelaku dan ganti rugi bagi korban atau masyarakat. ${ }^{5}$

Dalam berbagai cara dan model pendekatan Restorative Justice, proses dialog antara pelaku dan korban merupakan modal dasar dan bagian terpenting dari penerapan keadilan ini. Dialog langsung antara pelaku dan korban menjadikan korban dapat mengungkapkan apa yang dirasakannya, mengemukakan harapan akan terpenuhinya hak-hak dan keinginan-keinginan dari suatu penyelesaian perkara pidana. Melalui proses dialog juga pelaku diharapkan tergugah hatinya untuk mengoreksi diri, menyadari kesalahannya dan menerima tanggung jawab sebagai konsekuensi dari tindak pidana yang dilakukan dengan penuh kesadaran.

Dalam mekanisme penyelesaian perkara pidana dengan pendekatan Restorative Justice, maka posisi masyarakat bukan hanya sebagai peserta pelaku atau peserta korban saja. Masyarakat dapat berparsitipasi dan dapat diberikan peran yang lebih luas untuk menjadi pemantau atas pelaksanaan suatu hasil kesepakatan sebagai bagian dari penyelesaian perkara pidana melalui pendekatan ini. Pelaksanaan kegiatan ini dapat dilakukan dengan berbagai cara misalnya memantau upaya rehabilitasi korban, Memantau pelaksanaan pertanggung jawaban pelaku, yang dapat berwujud barbagai bentuk seperti perbaikan sarana yang rusak, pengembalian barang, pemenuhan denda adat dan lain sebagainya. dIl (sesuai dengan hasil kesepakatan)

${ }^{5}$ Ibid. Hlm. 194 
Dalam implementasinya mekanisme proses penerapan Restorative Justice menghendaki adanya keinginan untuk tetap memberikan perlindungan bagi pelaku anak. Akan tetapi, karena dalam proses Restorative mengharuskan adanya pengakuan bersalah terlebih dahulu. Setelah adanya pengakuan bersalah dari pelaku tindak pidana, penyidik juga harus melihat motivasi dari pelaku melakukan tindak pidana anak, apakah pada dasarnya anak ini adalah jahat, dan sebelumnya pernah melakukan tindakantindakan yang merugikan orang lain, ataukah dengan keadaan sedemikian rupa adanya keterpaksaan dalam melakukan tindak pidana anak. Selain motifasi penyidik harus melihat dampak kejahatan yang anak lakukan, serta membedakan kasus tindak pidana anak yang harus dibawa sampai ke pengadilan, dan mana kasus tindak pidana anak yang seharusnya tidak dibawa ke pengadilan

Salah satu cara untuk mempermudah dalam penerapan Restorative Justice adalah pihak kepolisian harus membuat satu tim khusus yang sudah dilatih dalam menangani permasalahan tentang anak agar dapat turun langsung menangani masalah dan berbaur dengan masyarakat. Sehingga bisa mengetahui secara langsung permasalahan yang terjadi di dalam masyarakat serta mencari solusi dan jalan keluar secara kekeluargaan.

Serangkaian proses Diversi dengan pendekatan Restorative Justice Dalam tahap penyidikan ini diharapkan penyidik dapat melaksanakannya dengan baik, dengan mengunakan kebijakankebijakan yang sesuai dengan hati nuraninya agar bisa terciptanya suatu perdamaian antara pelaku dan korban, serta mengembalikan lagi pelaku ke masyarakat tanpa adanya cap sebagai anak nakal atau anak pelaku tindak pidana. 
Karena tahap penyidikan adalah langkah awal seorang anak dalam menuju proses peradilan, melanjutkan proses peradilan atau mengembalikan ke masyarakat. Disitulah peran aparat penegak hukum yang harus bisa memaksimalkan proses Diversi dengan upaya Restorative Jastice secara seimbang Dan Sangat disayangkan apabila dalam tahap penyidikan tidak bisa terlaksananya Diversi yang kemudian anak dihadapkan dalam proses penuntutan.

Selanjutnya Dalam tahap penahanan terhadap pelaku tindak pidana anak tidak sama dengan penahanan pada umumnya. Dalam Pasal 21 ayat (1) Kitab Undang-Undang Hukum Acara Pidana (KUHAP) menjelaskan:

1. Diduga keras melakukan tindak pidana berdasarkan bukti yang cukup;

2. Dalam hal adanya keadaan yang menimbulkan kekhawatiran bahwa tersangka atau terdakwa akan melarikan diri, merusak, atau menghilangkan barang bukti;

3. Mengulangi tindak pidana

Dalam praktik penyidik atau Jaksa Penuntut Umum serta Hakim yang melakukan penahanan, mempergunakan syarat-syarat yang telah ditentukan dalam Pasal 21 ayat (1) KUHAP. Apakah seorang anak yang masih di bawah umur yang kemudian ditahan dengan alasan bahwa akan melarikan diri padahal anak tersebut memiliki identitas dan keluarga yang jelas, atau masih pantaskah menahan seorang anak yang tertangkap tangan melakukan suatu tindak pidana, dan barang buktinya telah disita yang berwajib. Apa relevansinya menjadikan syarat penahanan bagi tersangka adanya kekhawatiran menghilangkan barang bukti, sedangkan barang bukti tersebut sudah disita pihak yang berwajib.

Proses penahanan menurut Pasal 32 ayat (1) Undang-Undang 
Sistem Peradilan Pidana Anak, penahanan terhadap anak tidak boleh dilakukan dalam hal anak memperoleh jaminan dari orang tua/wali dan/atau lembaga bahwa anak tidak akan melarikan diri, tidak akan merusak atau menghilangkan barang bukti, dan/atau tidak akan mengulangi tindak pidana.

Tahapan setelah penyidikan adalah penuntutan, yang dijalankan oleh penuntut umum. Menurut Pasal 42 ayat (1) UndangUndang Sistem Peradilan Pidana Anak bahwa "Penuntut Umum wajib mengupayakan Diversi paling lama 7 (tujuh) hari setelah menerima berkas perkara dari penyidik". Pada tahap penuntutan penuntut umum wajib mengupayakan pengalihan hukum demi kepentingan terbaik bagi pelaku anak melalui pendekatan Keadilan Restoratif. Dalam hal proses Diversi berhasil mencapai kesepakatan, penuntut umum menyampaikan berita acara Diversi beserta kesepakatan Diversi kepada ketua Pengadilan Negeri untuk dibuat penetapan. Apabila dalam hal Diversi gagal penuntut umum wajib menyampaikan berita acara Diversi dan melimpahkan perkara ke pengadilan dengan melampirkan laporan hasil penelitian kemasyarakatan.

Apabila di setiap perkara yang dilakukan oleh anak di bawah umur menerapkan Restorative Justice, secara tidak langsung dapat mengurangi anak yang ditahan di dalam rutan maupun lapas, dan berkurangnnya perkara yang masuk ke pengadilan, mengurangi jumlah narapidana yang ada di dalam lembaga, mengurangi anggaran negara. Jika semua pelaku tindak pidana dalam hal ini yang termasuk dalam kejahatan ringan yang dilakukan oleh anak di bawah umur, kemudian dimasukan kedalam lembaga pemasyarakatan sangat tidak memiliki nilai guna karena hanya berdampak buruk terhadap anak itu sendri. 
Anak yang seharusnya mendapatkan bimbingan, masih sangat membutuhkan pengetahuan seperti sekolah dan kasih sayang kemudian berbaur dengan para tahanan lainya yang nantinya hanya akan terkontaminasi dari sifatsifat jahat. Sehingga dapat dikatakan pelaksanaan pemidanaan sesungguhnya belum tepat apabila masih dapat dicari jalan keluarnya. Yang sangat diperlukan adalah disetiap masalah yang bermunculan, bersama-sama masyarakat dan penegak hukum dan kedua belah pihak yang berperkara harus mencari solusi-solusi pada setiap persoalan anak, sehingga yang tadinya korban mempunyai emosional yang tinggi tidak lagi melaporkan kepada penegak hukum karena dapat menyelesaikan masalahnya dengan solusi yang tepat.

\section{Kendala Dalam Mewujudkan Restorative Justice Terhadap Pelaku Tindak Pidana Anak}

Restorative justice sebagai salah usaha untuk mencari penyelesaian konflik secara damai di luar pengadilan masih sulit diterapkan. Munculnya ide Diversi dalam upaya Restorative Justice sebagai kritik atas penerapan sistem peradilan pidana dengan pemenjaraan yang dianggap tidak efektif menyelesaikan konflik sosial. Penyebabnya, pihak yang terlibat dalam konflik tersebut tidak dilibatkan dalam penyelesaian konflik. Korban tetap saja menjadi korban, pelaku yang di penjara juga memunculkan persoalan baru bagi keluarga dan sebagainya.

Dengan adanya Diversi melalui pendekatan Restorative Justice diharapkan dapat menyentuh beberapa aspek bagi anak yang berhadapan dengan hukum yaitu pencegahan, penanganan, 
rehabilitasi dan reintegrasi. Namun ternyata tidak semua pihak dapat melaksanakan keempat aspek tersebut dengan pertimbangan bahwa semakin banyak yang terlibat dalam penanganan langsung terhadap anak yang berhadapan dengan hukum dapat memberikan imbas dan kendala secara teknis.

Kendala-kendala dalam mewujudkan Restorative Justice Terhadap Pelaku Tindak Pidana Anak adalah :

1. Pada aparat penegak hukum

dalam tingkat Kepolisian adalah rendahnya pemahaman anggota Polri terhadap konsep Restorative Justice. Anggota Polri secara umum sering mendengar penyebutan istilah Restorative Justice, tetapi pada kenyataannya tidak sedikit anggota yang belum paham dengan istilah tersebut, apalagi menerapkannya. Karena konsep tersebut relatif baru dalam penegakan hukum pidana.

Terlebih lagi dalam Undang-Undang Nomor 2 Tahun 2002 tentang Polri hanya mengenalkan konsep Diskresi kepolisian. Yang terdapat dalam Pasal 18 Undang-Undang Nomor 2 Tahun 2002 tentang Polri sehingga memberikan peluang pada aparat kepolisian untuk menerapkan Diskresi sebagai tindakan yang tidak menyimpang, namun dalam praktik penyelenggaraan tugastugas kepolisian, masih banyak aparat kepolisian yang ragu untuk menggunakan wewenang ini, terutama dalam penanganan kasus pidana anak.

Dalam menerapkan atau mengimplementasikan konsep kedilan Restorative penyidik Polri acap kali mengalami keraguraguan dalam mengambil keputusannya pada proses penyidikan anak pelaku tindak pidana yang memenuhi unsur-unsur tindak pidana, terutama apabila pelaku/ keluarganya dan korban/ 
keluarganya maupun msyarakat ternyata menginginkan perdamaian dalam penyelesaian kasus atau perkaranya. Hal ini disebabkan karena tidak adanya aturan ataupun payung hukum yang mengatur dan menjadi landasan legitimasi dalam mengambil keputusan pada proses penyidikan apakah berdasarkan konsep Restorative Justice atau konsep pendekatan lain yang bersesuaian dengan aliran Sociological Jurisprudence. sehingga situasi ini menjadi hal yang dilematis bagi penyidik Polri di lapangan yang berdasarkan pada faktor- faktor:

Kekawatiran atau ketakutan penyidik akan dipersalahkan oleh pimpinan atau atasan dan dipermasalahkan pada pengawasan dan pemeriksaan oleh institusi pengawas dan pemeriksa internal Polri yang menggunakan parameter formal prosedural.

2. Pihak Kejaksaan

Kejaksaan Tinggi kurang mengefektifkan bimbingan dan pengawasan jalannya penuntutan terhadap anak pelaku tindak pidana. Pihak Kejaksaan belum mengefektifkan kelompok Kerja Penanganan anak pelaku tindak pidana kurang melakukan sosialisasi internal soal anak pelaku tindak pidana.

3. Pada Masyarakat :

Masih adanya persepsi negatif masyarakat terhadap anak nakal sebagai pelaku kejahatan dan kesadaran masyarakat kurang mendukung reintegrasi dan rehabilitasi sosial bagi anak pelaku tindak pidana. serta Pengucilan dan stigmatisasi pelaku kejahatan terhadap anak pelaku tindak pidana meski telah menjalani hukuman atau dijalaninya masa bimbingan lanjut

4. Aspek Budaya Masyarakat:

Masih sedikitnya model pembinaan berbasis kearifan lokal 
dan budaya masyarakat dan Keterbatasan pembinaan anak pelaku tindak pidana dengan pendekatan budi pekerti dan keagamaan.

\section{PENUTUP}

\section{Kesimpulan}

Kewajiban mengupayakan Diversi dengan pendekatan Restorative Justice disetiap tahapan-tahapan dalam proses peradilan pidana anak yang terdapat di dalam Undang-Undang Nomor 11 Tahun 2012 tentang Sistem Peradilan Pidana Anak merupakan cara yang sangat baik dalam upaya memberikan perlindungan hukum pada proses peradilan pidana anak, memberikan perlindungan yang sesuai dengan Pasal 17 UndangUndang Nomor 11 Tahun 2012 dan Pasal 59 Undang-Undang Nomor 23 Tahun 2002 tentang Perlindungan Anak. Diversi sebagai langkah pengalihan penyelesaian perkara Anak dari proses peradilan pidana ke proses di luar peradilan pidana dengan mengutamakan pendekatan Restorative Justice yang dapat dilakukan dengan cara musyawarah atau mediasi yang menekankan upaya pemulihan kembali pada keadaan semula secara kekeluargaan

\section{Saran}

Ketika seorang anak terlibat dalam peradilan diperlukan adanya dukungan dan partisipasi dari masyarakat untuk melaksanakan penyelesaian di luar sistem peradilan pidana anak dengan pendekatan restorative justice. Dalam upaya pemulihan masyarakat dapat sebagai pengawas dan masyarakat harus bisa mema'afkan dan menerima kembali seorang anak yang melakukan suatu tindak pidana kedalam lingkungan masyarakat tanpa adanya persepsi negatif dan membimbingnya kembali untuk 


\section{DAFTAR PUSTAKA}

\section{A. Buku}

Alex Sobur, 1991, Komunikasi Orang Tua dan Anak, Angkasa, Bandung

Darwan Prinst, 1997, Hukum Anak Indonesia, Citra Aditya Bakti, Bandung

Hanafi, 1986, Asas-asas Hukum Islam, cet. ke-3, Bulan Bintang, Jakarta

Haliman, 1991, Hukum Pidana Syariat Islam menurut Ajaran Ahl alSunnah, Bulan Bintang, Jakarta

Lilik Mulyadi, 2005, Pengadilan Anak di Indonesia, Teori, Praktek dan Permasalahannya, Mandar Maju, Bandung

Marlina, 2009, Peradilan Pidana Anak Di Indonesia Pengembangan Konsep Diversi Dan Restoratif Justic, Rafika Aditama, Bandung

Moch. Faisal Salam, 2005 Hukum Acara Peradilan Anak di Indonesia, Cetakan I Mandar Maju, Bandung

M. Joni dan Zulchaina, 1999, Aspek Hukum Perlindungan Anak Dalam Perspektif Konvensi Hak Anak, Citra Aditya Bakti, Bandung

Marsum, 1989, Jinayat (HPI), cet. ke-2, Perpustakaan Fak. Hukum UII, Yogyakarta

Peter Mahmud Marzuki, 2009, Penelitian Hukum, Kencana Prenada Media Group, Jakarta

Sambas, Nandang, 2011, Pembaharuan Sistem Pemidanaan Anak di Indonesia, edisi pertama, Graha Ilmu, Yogyakarta

Tolib Setady, 2010, pokok-pokok hukum panitensier indonesia, Alfabeta, Bandung

Umar Hasyim, 1969, Cara Mendidik Anak dalam Islam, cet. ke-2, Pelita, Bandung

Wagiati Soetodjo, 2006, Hukum Pidana Anak, Rafika Aditama, Bandung 


\section{B. Perundang - Undangan}

Undang-Undang Dasar Negara Republik Indonesia Tahun 1945.

Kitab Undang-Undang Hukum Acara Pidana

Kitab Undang-Undang Hukum Pidana

Kitab Undang-Undang No 39 Tahun 1999 Tak Asasi Manusia

Kitab Undang-Undang No 23 Tahun 2002 Tentang Perlindungan Anak

Kitab Undang-Undang No 4 Tahun 1979 Tentang Kesejahteraan Anak

Kitab Undang-Undang No 2 Tahun 2002 Tentang Polri

Perma No 4 Tahun 2014 Tentang Diversi 